\title{
Kompetencje informatyczne studentów filologii polskiej w latach 2010-2016
}

\section{Digital competence of students of Polish philology in the years 2010-2016}

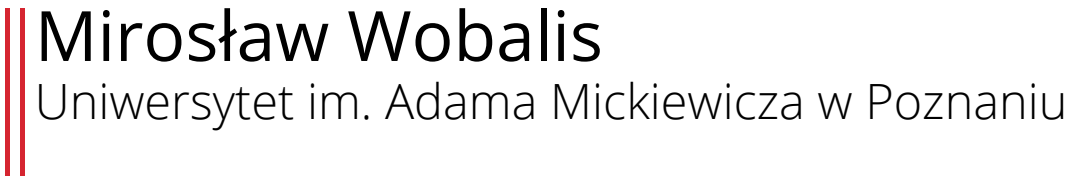

\begin{abstract}
The article talks about the digital competence of students of Polish Philology in the context of the dynamic development of technologies and the creation of the Information Society. The author presents the results of studies conducted in the years 2010-2016 on a group of 677 students who participated in a course "Scientific and Digital Education" held at the Faculty of Polish and Classical Philology at the Adam Mickiewicz University in Poznań. The results of the research represent the student's profile that has a significant gap in possessed and obtained, during previous stages of education, knowledge in the digital information technology, communication and the use of the Internet. As the research shows an average student has also inadequate skills in working with electronic documents, office tools and the Internet.
\end{abstract}

Key words: digital competence, technology, new media, computers, Internet, education.

Streszczenie: W artykule podjęty zostaje temat kompetencji informatycznych studentów Filologii Polskiej w kontekście dynamicznego rozwoju technologii i tworzenia się społeczeństwa informacyjnego. Zaprezentowane zostały wyniki badań przeprowadzonych w latach 2010-2016 grupie 677 studentów przedmiotu „Edukacja naukowo-informatyczna" prowadzonego na Wydziale Filologii Polskiej i Klasycznej Uniwersytetu im. Adama Mickiewicza w Poznaniu. Wyniki badań prezentują profil studenta, który posiada istotne braki zarówno w posiadanej i uzyskanej w poprzednich etapach edukacji, wiedzy dotyczącej technologii informatycznych, komunikacji i Internetu, jak też niewystarczające umiejętności w zakresie pracy z dokumentami elektronicznymi, narzędziami biurowymi i internetowymi.

Słowa kluczowe: kompetencje informatyczne, technologie, komputery, Internet, edukacja, nowe media.

Technologia informatyczna i edukacja są w drugim dziesięcioleciu XXI wieku mocno ze sobą powiązane i nic nie wskazuje, by w dającej się przewidzieć przyszłości uległo to zmianie - co więcej, integracja ta będzie coraz 
bardziej postępować (Kron, Sofos 2008). Interesujące nas obszary należy w tym kontekście rozumieć bardzo szeroko: w przypadku technologii mamy na myśli całą aktualną cyberprzestrzeń - od setek rodzajów urządzeń po wirtualną cyber-rzeczywistość Internetu. W przypadku edukacji zaś technologia ujawnia swoją obecność na wszystkich poziomach kształcenia (od zabaw edukacyjnych dla kilkulatków przez kształcenie instytucjonalne, do szkoleń i kursów skierowanych dla dorosłych aż do oferty edukacyjnej dla najstarszych). Trudno więc dziś, pisząc o edukacji, abstrahować od technologii i jej wpływu na uczniów, studentów, nauczycieli (Wobalis 2011). Co więcej, proces integracji technologii ze światem realnym (można go nazywać „światem analogowym” w przeciwieństwie do technologicznego „świata cyfrowego") sięga wszystkich przestrzeni życia współczesnego człowieka i ma w wymiarze cywilizacyjnym charakter stały, postępujący i niezmienny. Słusznie zauważa Lech W. Zacher (Zacher 2014, 14), że rozwój technologii tworzy wielkie i intensywne „fale innowacji” (występujących jednocześnie w wielu obszarach życia ludzi), które kumulują się w czasie i generują przemiany o charakterze gwałtownym i radykalnym. Są to nierzadko zmiany tak głębokie (jak wynalezienie pisma czy pojawienie się druku), że wpływają na globalny kierunek zmian w wymiarze cywilizacyjnym, kulturowym, społecznym. Nie ma najmniejszych wątpliwości, że współcześnie jesteśmy już nie świadkami, lecz uczestnikami (biernymi lub czynnymi) takiego właśnie procesu, który Alvin Toffler nazwał „Trzecią Falą” (Toffler, 1997), a John Naisbitt ostatnim wielkim cywilizacyjnym megatrendem rozwoju ludzkości (Naisbitt, 1997). W licznych dokumentach programowych, raportach i zestawach wytycznych najbardziej wpływowych instytucji (od ONZ przez Radę Europy po dokumenty krajowe ${ }^{1}$ ) okres ten nazywany jest społeczeństwem informacyjnym, erą wiedzy lub społeczeństwem sieciowym (Castells, 1996). Szkoła i edukacja widziane jako obszary i aktywności człowieka przez całe jego życie, zajmują istotne miejsce i pełnią ważną rolę w procesie przechodzenia współczesnych społeczeństw do nowego - „cyfrowego” etapu rozwoju ludzkości.

W związku z powyżej opisanymi procesami od lat 70. XX wieku obserwujemy silny społeczny i instytucjonalny nacisk (napotykający coraz słabszy opór) na stałe technologiczne modernizowanie instytucji - w tym instytucji edukacyjnych na każdym etapie kształcenia w celu dostosowania ich funkcjonowania do aktualnych wymogów i możliwości technologii². W przypadku edukacji, w tej rzeczywistości stale zmieniających

${ }^{1}$ Edukacja: jest $w$ niej ukryty skarb. Raport dla UNESCO Międzynarodowej Komisji ds. Edukacji Dwudziestego Pierwszego Wieku pod przewodnictwem Jacques'a Delorsa, 1998, Rabczuk W. (przeł.), Warszawa; Nauczanie i Uczenie się. Na drodze do uczacego się społeczeństwa. Biała Księga Komisji Europejskiej, 1997, Warszawa; Raport o Rozwoju Społecznym Programu Narodów Zjednoczonych ds. Rozwoju, 2002, red. W. Cellary, White Paper, 21 st Century Literacy Summit, 2002, AOL Time Warner Foundation - Bertelsmann Foundation, Berlin, Dynamiczna Polska 2020. Strategia innowacyjności i efektywności gospodarki, 2013, Warszawa i inne.

2 Por. Steinbrink B., 1993, Multimedia. U progu XXI wieku, Wrocław; Media a edukacja, t. 1, 2, 3, 1997, 1998, 2000, Strykowski W. (red.), Poznań; Bednarek J., 2002, Multimedia w kształceniu, Warszawa; Pedagogika medialna: podręcznik akademicki, 2007, Siemieniecki B. (red.), Warszawa. 
się uwarunkowań i wyzwań technologicznych, niezwykle istotne jest monitorowanie stopnia nasycenia technologiami w ramach samej szkoły ${ }^{3}$ oraz kompetencji technologicznych jednostek uczestniczących w procesie dydaktycznym: nauczycieli i uczniów ${ }^{4}$. Realizuje się to przez odgórne zalecanie/ narzucanie instytucjom spełniania wymogów technologicznych (pracownie komputerowe w każdej szkole, dostęp do szybkiego Internetu, integrowanie treści dydaktycznych z interaktywnymi narzędziami multimedialnymi, wprowadzanie interaktywnych e-dzienników, elektronicznych systemów zarządzania szkołą, promowanie cyfrowej ewaluacji itp.), prowadząc jednocześnie weryfikujące badania kompetencji informatycznych uczestników procesu na różnych poziomach kształcenia.

W Polsce, kraju „na cywilizacyjnym dorobku”, od lat 90. XX wieku do końca pierwszego dziesięciolecia wieku następnego pytano przede wszystkim o stopień komputeryzacji szkół, a więc o nasycenie szkół salami komputerowymi, o dostępność uczniów i nauczycieli do sal i urządzeń komputerowych, dostęp do pomocy multimedialnych, wreszcie (od końca lat 90. XX wieku aż do dzisiaj) o dostęp do sieci Internet ${ }^{5}$. W zakresie umiejętności weryfikowano głównie sprawności dotyczące podstawowej obsługi komputerów i innych urządzeń z grupy technologii informatycznych, umiejętność pracy z systemami operacyjnymi, plikami i folderami, biegłość w zakresie uruchamiania i obsługi podstawowych aplikacji komputerowych. W przypadku rozwijania kompetencji informatycznych uczniów w pierwszej kolejności skupiono się na umożliwieniu im uczestniczenia w zajęciach, które bezpośrednio koncentrowały się na podnoszeniu sprawności komputerowych. Na zajęciach informatyki (która od połowy lat 90. XX wieku stała się obowiązkowym przedmiotem szkolnym) uczono komend systemu MS-DOS oraz wprowadzano podstawowe pojęcia związane z programowaniem (np. języki BASIC czy PASCAL). W przypadku rozwijania umiejętności nauczycieli istotne stało się umożliwienie im dostępu do specjalistycznych szkoleń

\footnotetext{
${ }^{3}$. Można w tym miejscu wskazać liczne badania m.in. Osiecka-Chojnacka J., Komputeryzacja szkolnictwa. Sytuacja w Polsce na tle innych krajów Unii Europejskiej, Kancelaria Sejmu. Biuro studiów i ekspertyz, [Online] <http://biurose.sejm.gov.pl/teksty pdf 06/i-1253.pdf> (dostęp 01.09.2016), Jakubowski M., Computers at schools: it's not enough to have them and it's not enough to use them. IBS Policy Paper 6/2014, EC, Survey of Schools: ICT in Education, 2013, European Commission.

4 Jak nowe technologie pomagaja uczyć? Wyniki badań Edunews.pl wśród nauczycieli polskich szkół 2008-2009 [Online] <http://www.edunews.pl/images/pdf/jak nowe tech_pomagaja.pdf> (dostęp 01.09.2016), Międzynarodowe Badania Kompetencji Komputerowych i Informacyjnych ICILS 2013 [Online] <http://eduentuzjasci.pl/badania/206-publikacje/raport/raport-z-badania/kompetencje-komputerowe-i-informacyjne-mlodziezy-w-polsce/1135-kompetencje-komputerowe-i-informacyjne-mlodziezy-w-polsce-raport-icils.html> (dostęp 01.09.2016), Students, Computers and Learning. Making the Connection, PISA 2015 [Online] <http://www.oecd.org/education/students-computers-and-learning-9789264239555-en.htm > (dostęp 01.09.2016).

5 Dostęp do szerokopasmowego Internetu dla wszystkich szkół podstawowych i ponadpodstawowych w Polsce jest głównym celem programu „Internet dla szkół”, ogłoszonego 22 grudnia 2015 r. przez Ministerstwo Cyfryzacji wspólnie z Ministerstwem Edukacji Narodowej oraz Ministerstwem Nauki i Szkolnictwa Wyższego. Nie można nie skomentować, że jest to kolejny z wielu programów tego typu ogłaszanych co kilka lat przez instytucje centralne. W roku 2013 spośród 37160 szkół w Polsce dostępem do sieci Internet dysponowało 24623 szkół. Ze wszystkich typów szkół (podstawowe, gimnazjalne, licea ogólnokształcące oraz licea zawodowe i technika) dostęp do Internetu posiadało $83 \%$ szkół na wsiach, 64\% szkół zlokalizowanych w miastach do 5000 mieszkańców i 56\% szkół w miasta powyżej 5000 mieszkańców. Źródło: [Online] <http://natablicy.pl/men-wiekszosc-szkol-w-polsce-ma-dostep-do-internetu, artykul.html?material id=5245420db564da64148fc5bc> (dostęp 01.09.2016).
} 
komputerowych, szkoleń z zakresu obsługi urządzeń i oprogramowania komputerowego, które można byłoby wykorzystywać w ramach zajęć dydaktycznych. Z końcem lat 90. XX wieku w dyskursie naukowym dotyczącym pedagogiki medialnej ${ }^{6}$ coraz silniej podnoszona jest kwestia integrowania technologii informatycznej i metod kształcenia multimedialnego $\mathrm{w}$ ramach poszczególnych przedmiotów - w tym przedmiotów ściśle humanistycznych ${ }^{7}$.

Od końca pierwszego dziesięciolecia XXI wieku, wraz z naturalnym nasyceniem sprzętem oraz z wejściem na rynek pracy młodszych nauczycieli posiadających większą sprawność w zakresie technologii informatycznych, badanie kompetencji wyłącznie komputerowych oraz śledzenie stopnia nasycenia urządzeniami przestało odgrywać istotną rolę. W XXI wieku żyjemy już bowiem w świecie sieciowym ${ }^{8}$, świecie „online”, w którym jego mieszkańcy, obywatele „społeczeństwa sieciowego”, sporą część swojego dnia spędzają w rzeczywistości cyfrowej - cyberprzestrzeni, będącej połączeniem wirtualnego świata Internetu i multimedialnego i w coraz większym stopniu interaktywnego świata masowych multimediów (jak określa się współczesne radio, telewizję czy prasę). Współcześnie mamy już więc do czynienia z drugim wariantem badań kompetencji - skupiającym się na badaniu sprawności sieciowych nauczycieli i uczniów. Nie pytamy o to, czy młodzi w ogóle korzystają z technologii (ludzie urodzeni w roku 1990 nie znają przecież świata bez komputerów i Internetu), lecz zadajemy pytania dotyczące tego, „jak”, „w jaki sposób” z technologią młodzi żyją, jak spędzają swój czas wolny oraz jak wykorzystują technologie i sieć do nauki, pracy i rozrywki. Nie da się także ukryć, że istnieje jeszcze trzeci obszar badania kompetencji informatycznych - ten, w którym przedstawiciele pokolenia „cyfrowych imigrantów” (urodzonych daleko przed rokiem 1990) starają się rozpoznać (zrozumieć?) model życia współczesnych „cyfrowych tubylców" ${ }^{\prime 9}$. W badaniach, które zostaną zaprezentowane poniżej, wykorzystane zostaną wszystkie przedstawione wyżej warianty.

Od roku 2010 na Wydziale Filologii Polskiej i Klasycznej Uniwersytetu im. Adama Mickiewicza w Poznaniu prowadzę obowiązkowe zajęcia w wymiarze 30 godzin dla studentów pierwszego roku na kierunku filologia

${ }^{6}$ Zwłaszcza należy w tym miejscu wspomnieć o wieloletnich inicjatywach poznańskiego środowiska skupionego wokół Wacława Strykowskiego z Zakładu Technologii Kształcenia Wydziału Studiów Edukacyjnych Uniwersytetu im. Adama Mickiewicza w Poznaniu, organizatora cyklu międzynarodowych konferencji „Media a edukacja”, których dziewięć edycji odbyło się w latach 1997-2016.

7 Bogatą antologię polonistycznych programów multimedialnych przedstawiła Aleksandra Dziak w artykule Programy multimedialne $w$ edukacji polonistycznej, w: E-polonistyka, 2009, Dziak A., Żurek S.J., (red.), Lublin, s. 207-216; zob. Wobalis M., 2011, Multimedia $w$ nauczaniu polonistycznym. Opis modelu hybrydowego e-podrecznika języka polskiego do liceum i badanie jego efektywności dydaktycznej w szkole, „Poznańskie Studia Polonistyczne”, Poznań.

${ }^{8}$ M.in. Castells M., 1996, The Rise of the Network Society, wyd. pol. 2007, Społeczeństwo sieci, Warszawa; Dijk van J., 1997, De Netwerkmaatschappij, sociale aspecten van nieuwe media, wyd. ang. 1999, The Network Society: Social Aspects of New Media, wyd. pol. 2010, Społeczne aspekty nowych mediów. Analiza społeczeństwa sieci, Warszawa; Fowler J.H., Christakis N.A., 2009, Connected: The Surprising Power of Our Social Networks and How They Shape Our Lives, Little, Brown and Company, New York, wyd. pol. 2011, W sieci, Sopot.

9 "Cyfrowi tubylcy” i „cyfrowi imigranci” to określenia Marca Prensky’ego pochodzące z pracy: Prensky M., 2001, Digital Natives, Digital Immigrants, w: On the Horizon, Vol. 9 No. 5, MCB University Press, Bradford. 
polska pod nazwą „Edukacja naukowo-informatyczna”. Tworząc program zajęć, założono, na podstawie analizy dokumentów programowych kształcenia na poziomach wcześniejszych - zwłaszcza w gimnazjum i w szkołach średnich, że uczniowie nabywają podstawowy zasób wiedzy i umiejętności informatycznych w szkole (w zakresie pojęć dotyczących społeczeństwa informacyjnego, multimediów, tworzenia i edycji dokumentów elektronicznych ${ }^{10}$. Praktyczne i obowiązkowe warsztaty akademickie ENI mają za zadanie wprowadzenie studentów w obszar wiedzy i umiejętności bardziej zaawansowanych, wyrobienie postaw krytycznych wobec świata interaktywnego, a także nauczenie umiejętności przydatnych w pracy naukowej. W warstwie teorii wprowadza się pojęcia związane z teorią komunikacji, społeczeństwem informacyjnym i jego cechami, mediami i multimediami, Internetem, hipertekstem, bazami danych oraz cyfrowymi repozytoriami. W zakresie ćwiczeń i warsztatów studenci nabywają umiejętności tworzenia interaktywnych spisów bibliograficznych, sprawnego i efektywnego wykorzystywania bibliotek cyfrowych i repozytoriów. W trakcie zajęć studenci uczą się podstawowych zasad edytorstwa naukowego, tworzą rozbudowane dokumenty tekstowe i prezentacje. Na warsztatach poświęconych Internetowi uczą się korzystać z usług sieciowych, zaawansowanych form wyszukiwania informacji, tworzą własne domeny oraz samodzielnie zakładają i konfigurują serwis internetowy oparty na skrypcie PHP i obsłudze baz danych. Głównym celem zajęć jest przygotowanie studentów do efektywnej pracy naukowej ze źródłami oraz dokumentami elektronicznymi również w zakresie ich druku i publikacji.

W latach 2010-2016 przeprowadziłem zajęcia siedmiokrotnie, za każdym razem poddając studentów kilkustopniowym badaniom, w których łącznie wzięło udział 677 respondentów (roczniki i badane grupy nie były równe, jednak w każdym roku przekraczały 100 osób). W każdym roku badanie składało się z pięciu etapów i obejmowało: a) interaktywny test wiedzy teoretycznej z zakresu technologii informacyjnych na poziomie podstawowym na początku i na końcu zajęć; b) anonimową ankietę, w której studenci odpowiadają na 30 pytań dotyczących posiadanego sprzętu, sposobów korzystania z technologii, form aktywności w Internecie, subiektywnej oceny swoich umiejętności informatycznych w zakresie edycji tekstu, korzystania z aplikacji biurowych oraz narzędzi internetowych; ankieta służy również sprawdzeniu, jak studenci oceniają obecność technologii

\footnotetext{
10 Zgodnie z zapisami podstaw programowych przedmiotu informatyka w gimnazjum uczeń: „przy użyciu edytora tekstu tworzy kilkunastostronicowe publikacje, z nagłówkiem i stopką, przypisami, grafiką, tabelami itp., formatuje tekst w kolumnach, opracowuje dokumenty tekstowe o różnym przeznaczeniu" [Online] Ministerstwo Edukacji Narodowej https://men.gov.pl/wp-content/uploads/2011/02/6e.pdf s. 104, (dostęp 01.09.2016), zaś w liceum uczeń: „opracowuje wielostronicowe dokumenty o rozbudowanej strukturze, stosuje style i szablony, tworzy spis treści”, tamże s. 108. Warto dodać, że wielostronicowe podstawy programowe do tego przedmiotu są bardzo rozbudowane i zawierają wiele potrzebnych informacji oraz praktyczny zasób umiejętności. O „powinnościach polonisty" w tym kontekście wyczerpująco pisałem w: M. Wobalis, 2011, Multimedia i ich wpływ na edukacje i uczenie się, w: Innowacje i metody. Tom 1. W kręgu teorii i praktyki. Podręcznik akademicki dydaktyki kształcenia polonistycznego, Kwiatkowska-Ratajczak M. (red.), Poznań, s. 237-248.
} 
informacyjnych w gimnazjum i szkole średniej oraz na lekcjach języka polskiego - w tym ocenę kompetencji informatycznych nauczycieli; c) praktyczną weryfikację umiejętności studentów w trakcie ćwiczeń z edycji tekstu (w zakresie praktycznych umiejętności edytorskich założonych w podstawach programowych dla szkoły średniej); d) analizę samodzielnej wypowiedzi studentów dotyczącej oceny zagrożeń związanych z technologiami informacyjnymi i Internetem; e) ankietę oceniającą zajęcia (w zakresie wprowadzonych treści, ćwiczeń i metod pracy).

Głównym celem tak zaplanowanych badań było zweryfikowanie kompetencji informatycznych studentów pierwszego roku - absolwentów szkół ponadgimnazjalnych, w zakresie ich wiedzy ogólnej dotyczącej najważniejszych pojęć związanych z kształtującym się społeczeństwem informacyjnym i technologiami informatycznymi jako podstawowymi narzędziami pracy, nauki i codziennego życia współczesnego człowieka. W zakresie umiejętności posługiwania się narzędziami badania zweryfikować miały stopień praktycznego przygotowania absolwentów szkół średnich do funkcjonowania $\mathrm{w}$ realiach społeczeństwa informacyjnego - ze szczególnym uwzględnieniem sprawnego posługiwania się narzędziami komputerowymi (aplikacje biurowe) i internetowymi (wyszukiwarki, bazy danych) w pracy i nauce. Warto podkreślić, że studenci wybierający kierunek polonistyczny nie różnią się pod względem dostępu do technologii oraz obsługi narzędzi informatycznych (urządzeń i oprogramowania) od pozostałych rówieśników. Wszyscy oni należą do pokolenia „cyfrowych tubylców” i zgodnie $\mathrm{z}$ wynikami wielu badań kompetencji informatycznych ${ }^{11}$ prowadzonych na różnych poziomach rozwoju, doskonale obyci są z najnowocześniejszą technologią. To klasyczni hybrydowi komunikatorzy (Puppel, 2008) funkcjonujący/zanurzeni w świecie hybrydowej komunikacji (Zacher, 2014). Biorąc jednak pod uwagę specyfikę ich zainteresowań (literatura, język, kultura) oraz moment w rozwoju sprzyjający krytycyzmowi, można zakładać, że ich stosunek do technologii i świata przesyconego multimediami może być specyficzny i odmienny od rówieśników wybierających kierunki ścisłe lub przyrodnicze. W związku z tym ważnym celem jakościowym tak zaplanowanych badań było także zbadanie stosunku najmłodszych studentów filologii polskiej do technologii, świadomości zagrożeń oraz umiejętności radzenia sobie z nimi. Spora część z badanych studentów w przyszłości stanie się nauczycielami, w związku z tym analiza ich wypowiedzi jest również okazją do określenia najważniejszych zadań stojących przed

${ }^{11}$ M.in. Międzynarodowe Badania Kompetencji Komputerowych i Informacyjnych ICILS 2013 [Online] <http://eduentuzjasci.pl/badania/206-publikacje/raport/raport-z-badania/kompetencje-komputerowe-i-informacyjne-mlodziezy-w-polsce/1135-kompetencje-komputerowe-i-informacyjne-mlodziezy-w-polsce-raport-icils.html> (dostęp 01.09.2016), Kompetencje komputerowe i informacyjne młodzieży w Polsce, 2014, Sijko K. (red.), Instytut Badań Edukacyjnych, Warszawa. 
akademickim kształceniem nauczycieli języka polskiego w zakresie kompetencji informatycznych.

W warstwie dydaktycznej celem badania było przeprowadzenie ewaluacji zajęć, które z założenia prowadzone były w formule eksperymentalnej realizowanej w trzech wariantach wykorzystania technologii informatycznych: a) jako wsparcia zajęć realizowanych w pełnym zakresie w pracowni komputerowej, b) jako kursu realizowanego w formule mieszanej: część zajęć w pracowni pod kierunkiem nauczyciela, część w formie samodzielnej, zdalnej pracy studenta na platformie informatycznej (blended learning), c) pełny kurs zdalny realizowany poprzez platformę informatyczną (e-learning). Ankieta ewaluacyjna oraz analiza ocen uzyskanych przez studentów w różnych wariantach miała za zadanie udzielenie odpowiedzi na pytanie o najefektywniejszą formułę realizacji tego typu zajęć w realiach kształcenia akademickiego.

W każdym roku prowadzenia badań kompetencji informatycznych studentów formuła przeprowadzenia badań wyglądała identycznie. W trakcie pierwszych zajęć w pracowni komputerowej studenci logowali się do kursu przedmiotu „Edukacja naukowo-informatyczna” znajdującego się na Wydziałowej Platformie Informatycznej WFPiK UAM i otrzymywali dostęp do informacji ogólnych związanych z kursem (sylabus, program zajęć, plan konsultacji, informacje techniczne, dane kontaktowe), dostęp do interaktywnej ankiety oraz dostęp do interaktywnego testu. W pierwszej kolejności studenci wypełniali interaktywną ankietę, która składała się z 30 pytań podzielonych na trzy grupy: 15 pytań dotyczyło posiadanych przez studentów urządzeń i sposobów korzystania z technologii informatycznych i form aktywności w Internecie, 10 pytań skupiało się na subiektywnej ocenie własnych umiejętności informatycznych w zakresie edycji tekstu, korzystania z aplikacji biurowych oraz narzędzi internetowych, 5 pytań koncentrowało się na tym, jak studenci oceniali obecność technologii informacyjnych w szkole średniej i na lekcjach języka polskiego - w tym ich ocenę kompetencji informatycznych nauczycieli. Ze względu na dynamiczne zmiany na rynku technologii (pojawianie się nowych urządzeń i usług) w trakcie sześciu lat prowadzenia badań ankieta była modyfikowana cztery razy: największe zmiany wprowadzone zostały w roku 2012 w związku z szerokim upowszechnieniem się smartfonów, tabletów oraz usług taniego Internetu dostępnego na urządzeniach przenośnych. Na wypełnienie ankiety studenci mieli 20 minut, po czym przechodzili do interaktywnego testu, na wypełnienie którego otrzymywali kolejne 60 minut (czas odmierzany był na ekranie aplikacji).

Test początkowy składał się z 60 interaktywnych pytań zamkniętych (pytań prawda/fałsz, wielokrotnego wyboru, wielokrotnego zaznaczenia odpowiedzi) losowanych z bazy 300 pytań. Pytania dotyczyły podstawowych pojęć i terminów dotyczących mediów, multimediów, komunikacji, informatyki, Internetu, edytorstwa, obsługi komputerów i systemów operacyjnych 
oraz pojęć dotyczących głównych zjawisk związanych ze społeczeństwem informacyjnym. W zdecydowanej większości, bo aż 197 pytań, pochodziło z najpopularniejszych podręczników szkolnych dla przedmiotu „zajęcia komputerowe” do szkoły podstawowej („Klik plik” wydawnictwa PWN, „Lekcje z komputerem” wydawnictwa WSiP), dla przedmiotu informatyka w gimnazjum („Klik plik” wydawnictwa PWN, „Po prostu informatyka” wydawnictwa WSiP) oraz „Po prostu informatyka” wydawnictwa WSiP dla przedmiotu informatyka do szkół ponadgimnazjalnych.

Pytania zostały podzielone na bardzo łatwe (100 pytań) ${ }^{12}$ i dotyczące podstawowych pojęć dotyczących mediów, obsługi komputera, przeglądarki internetowej czy edytora tekstu, łatwe (75) ${ }^{13}$ - gromadzące w większości pytania z dziedziny informatyki, systemów operacyjnych, aplikacji komputerowych i skomplikowane (75) - skupiające pytania z dziedziny zabezpieczeń komputerowych, narzędzi systemowych oraz zaawansowanej edycji tekstu ${ }^{14}$. Pytania trudne, które nie zostały znalezione w podręcznikach szkolnych, stanowiły najmniej liczną grupę 50 pytań i dotyczyły zjawisk społecznych związanych z rozwojem społeczeństwa informacyjnego oraz specjalistycznych pojęć informatycznych czy też dotyczących baz danych i języków programowania ${ }^{15}$. Test modyfikowany był jednorazowo w roku 2015 - usunięto z niego kilkanaście wyraźnie przestarzałych pytań. Jak wspomniano wyżej, w przypadku testu początkowego studenci mieli 60 minut na odpowiedź na 60 pytań, przy czym nie wolno im było korzystać z żadnych dodatkowych pomocy - w szczególności z wyszukiwarek internetowych. Do tego samego testu studenci podchodzili na końcu zajęć. Tym razem w ciągu 80 minut musieli odpowiedzieć na 150 losowych pytań - mieli więc na udzielenie odpowiedzi znacznie mniej czasu niż w teście początkowym. Warto w tym miejscu zaznaczyć, iż konstrukcja programowa kursu ENI zakładała, że pierwsze cztery jednostki zajęć przeznaczone były na omówienie zagadnień teoretycznych i kończyły się testami interaktywnymi zawierającymi pytania z poświęconej im problematyki - odpowiednio były to: „Społeczeństwo informacyjne, teoria komunikacji, media i multimedia”; „Komputery i systemy operacyjne”; „Internet i narzędzia internetowe”, „Edycja tekstu”. Materiały dydaktyczne (prezentacje multimedialne oraz ćwiczenia) dostępne były dla studentów na platformie do końca zajęć. Tak więc studenci, którzy aktywnie uczestniczyli w zajęciach lub aktywnie

\footnotetext{
12 Przykładowe pytania z tej grupy: „Jakim znakiem specjalnym oddziela się w adresie e-mail nadawcę wiadomości od nazwy domeny pocztowej? a) @, b) \#, c) \&”; „Który klawisz na klawiaturze komputerowej służy do oddzielania znaków lub wyrazów? a) Enter, b) Spacja, c) Alt; „Telewizja należy do grupy mediów: a) wizualnych, b) dźwiękowych, c) audiowizualnych”.

13 Przykładowe pytanie z tej grupy: „Drukarka komputerowa należy do grupy urządzeń: a) wejścia, b) wyjścia”, „Systemem operacyjnym nie jest: a) Chrome, b) Windows, c) Android; „Wskaż nazwę przeglądarki internetowej: a) Windows, b) Opera, c) Photoshop”;

14 Przykładowe pytanie z tej grupy: „Całkowicie odporni na ataki internetowych hakerów (przez wirusy i trojany) jesteśmy, gdy: a) Mamy zainstalowany program typu firewall, b) Spędzamy mało czasu w Internecie, c) Nie korzystamy z Internetu, d) Mamy zainstalowany równocześnie firewall i program antywirusowy".

15 Przykładowe pytanie z tej grupy: „Alvin Toffler jest autorem książki: a) „Megatrendy cywilizacji”, b) „Trzecia Fala”, c) „Kryzys cywilizacji”, d) „Media i multimedia w czasach przełomu”.
} 
korzystali z pomocy dydaktycznych zamieszczonych na platformie, zetknęli się ze wszystkimi zagadnieniami, które pojawiły się w pytaniach testowych. Dodatkowo w trakcie testu końcowego studenci mogli korzystać z własnych notatek oraz pomocy dydaktycznych dostępnych na platformie (mieli na to jednak bardzo niewiele czasu).

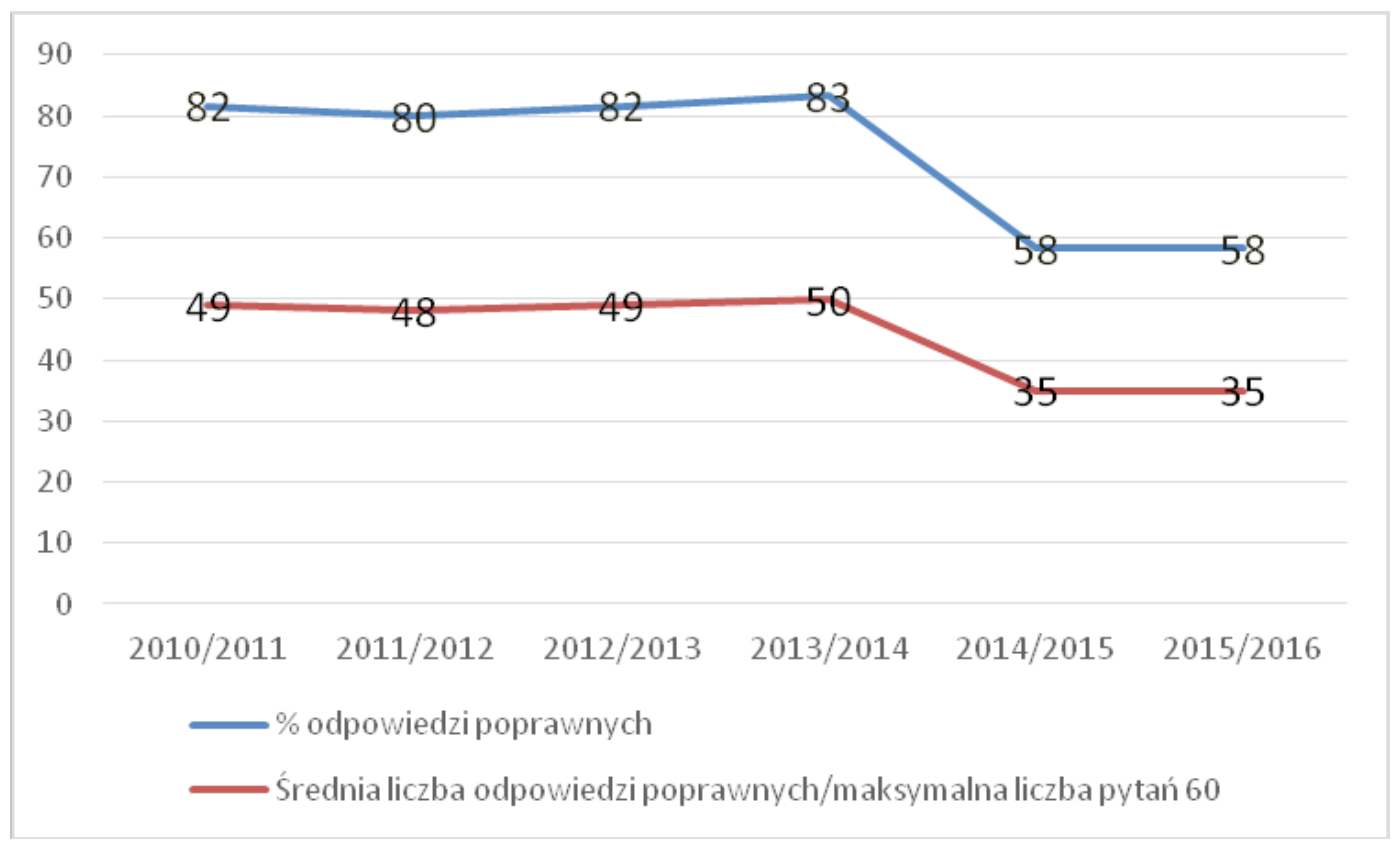

Wykres nr 1. Wyniki testu wprowadzającego w poszczególnych latach prowadzenia badań

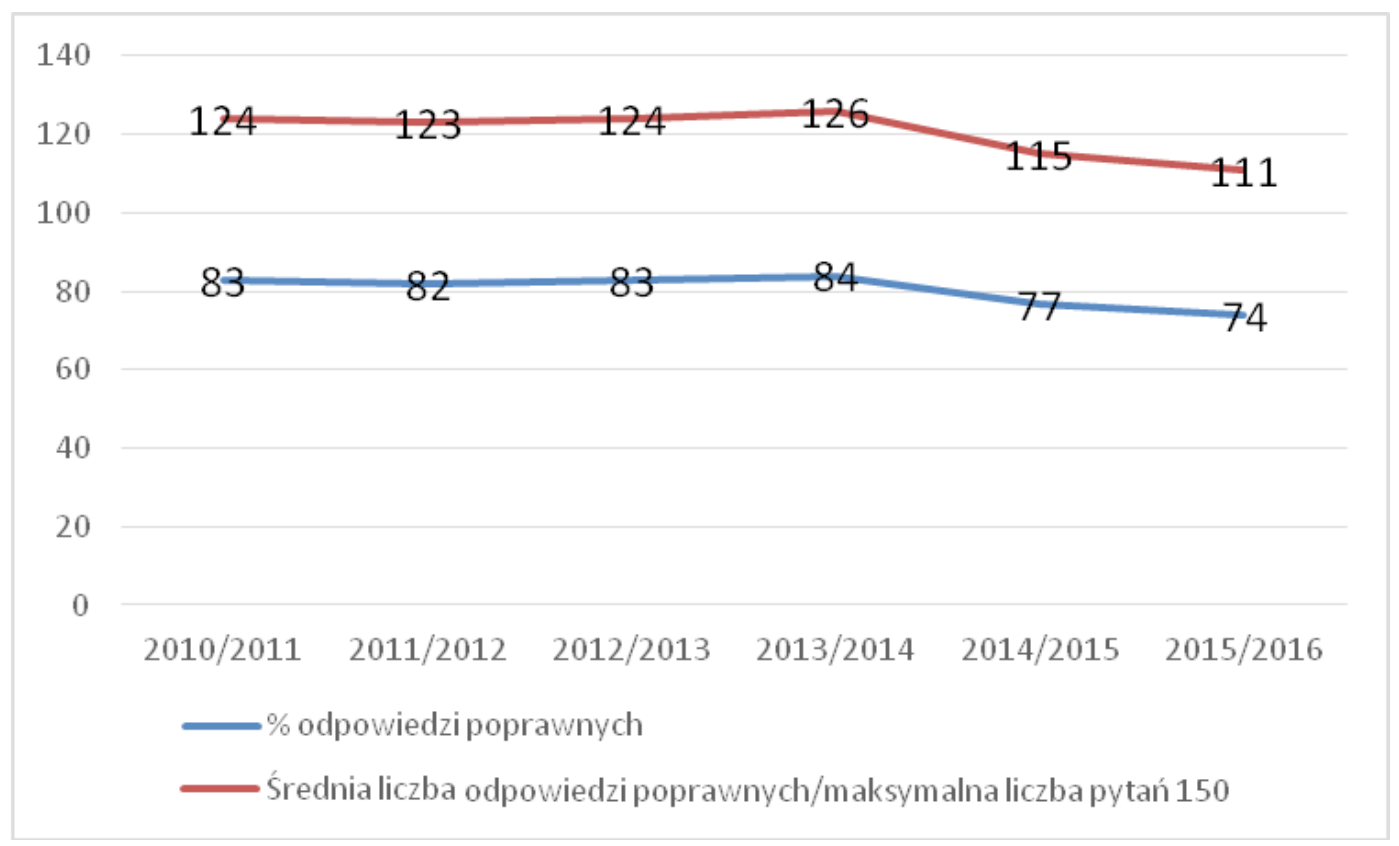

Wykres nr 2. Wyniki testu końcowego

Polonistyka. Innowacje 
Wyniki z lat 2010-2014 wskazują na satysfakcjonujący poziom kompetencji uzyskiwanych przez studentów we wcześniejszych etapach edukacji w interesującym mnie zakresie tematycznym. Porównanie liczby punktów i procentu poprawnych odpowiedzi uzyskanych w testach początkowych oraz końcowych dowodzi, że zajęcia przyniosły oczekiwany efekt związany ze zwiększeniem kompetencji studentów w zakresie wiedzy teoretycznej. Zastanawiające mogą wydawać się wyniki testu początkowego z roku akademickiego 2014/15 i 2015/16 wyraźnie odbiegające od wyników uzyskiwanych przez studentów w latach wcześniejszych. O ile w latach 20102014 liczba osób, które nie zdały testu początkowego mieściła się w zakresie $20-25 \%$, to od roku akademickiego 2014/15 w dwóch rocznikach liczba osób, które zdały test, nie przekroczyła w żadnej z 14 grup 10\%... Wyniki te wskazują, że na wcześniejszym etapie edukacji nastąpiły zmiany, które spowodowały obniżenie się kompetencji studentów w tym obszarze. Pewnym tropem (który jednakże zasługuje na dokładniejsze zbadanie) może być fakt, że w roku akademickim 2014/15 na uczelniach wyższych pojawił się po raz pierwszy rocznik, który od początku do końca edukacji powszechnej realizował tak zwaną nową podstawę programową ${ }^{16}$. W trakcie rozmów ze studentami, którzy jako nieliczni uzyskiwali wyniki pozytywne, okazywało się, że albo są z roczników starszych, w szkole uczęszczali na zajęcia rozszerzone $\mathrm{z}$ informatyki, albo technologie i zagadnienia związane $\mathrm{z}$ technologiami są im bliskie.

Interesująco przedstawiają się również wyniki badań dotyczących oceny własnych kompetencji informatycznych oraz ich weryfikacji w trakcie ćwiczeń w pracowni. Szczególnej obserwacji poddane zostały kompetencje w zakresie pracy z edytorem tekstu w trakcie ćwiczeń warsztatowych dotyczących edycji (składu, formatowania i redakcji) rozbudowanego dokumentu tekstowego składającego się z kilkudziesięciu stron tekstu, okładki, spisu treści, indeksów, tabeli oraz wykresu ${ }^{17}$. O ile $\mathrm{w}$ ankiecie studenci w zdecydowanej większości deklarowali dobre i bardzo dobre kompetencje w zakresie edycji tekstu oraz tworzenia prezentacji multimedialnych, to w trakcie zajęć ich umiejętności okazywały się dobre wyłącznie w przypadku najprostszych operacji polegających na zmianie wielkości lub koloru czcionki. Większość poleceń typowo edytorskich związanych na przykład z wyjustowaniem tekstu, wstawieniem wcięć akapitowych, usunięciem błędnych lub niewłaściwych znaków (np. cudzysłowów angielskich) stanowiła dla nich nowość, co wskazuje, że na żadnym wcześniejszym etapie edukacji nie wprowadza się ćwiczeń polegających na tworzeniu dokumentów tekstowych i prostych (najprostszych nawet) ćwiczeń z edycji tekstu.

W każdym roczniku około $10-15 \%$ studentów posiadało w tym zakresie kompetencje bardzo niskie, ujawniające się na przykład w trudności

\footnotetext{
${ }^{16}$ Poza uczniami technikum, którzy w roku szkolnym 2014/15 realizowali w klasie czwartej tzw. starą podstawę programową, stopniowo wygaszaną od 1 września 2009 roku.

${ }_{17}$ Jest to więc zakres umiejętności zgodny z cytowanym w przypisie nr 13 i zapisanym w podstawie programowej przedmiotu informatyka zakresem umiejętności ucznia gimnazjum! 
w posługiwaniu się klawiaturą (brak wiedzy w układzie klawiszy funkcyjnych typu shift, alt, delete) i całkowitym brakiem umiejętności edycji tekstu $^{18}$. Z rozmów prowadzonych ze studentami w trakcie zajęć jasno wynikało, że w szkole średniej na żadnym przedmiocie nie pojawiły się ćwiczenia związane z edycją tekstu i tworzeniem prezentacji - większość umiejętności, z którymi młodzi ludzie wchodzą w świat społeczeństwa informacyjnego, nabywana jest samodzielnie, mimochodem i poza szkołą. Na wykresie nr 3 znajdują się wskazania własnych kompetencji studentów pojawiające się $\mathrm{w}$ ankiecie oraz uśrednione oceny z trzech ćwiczeń edytorskich realizowanych w trakcie zajęć (każde ćwiczenie oceniane było w skali od 1 do 100 punktów).

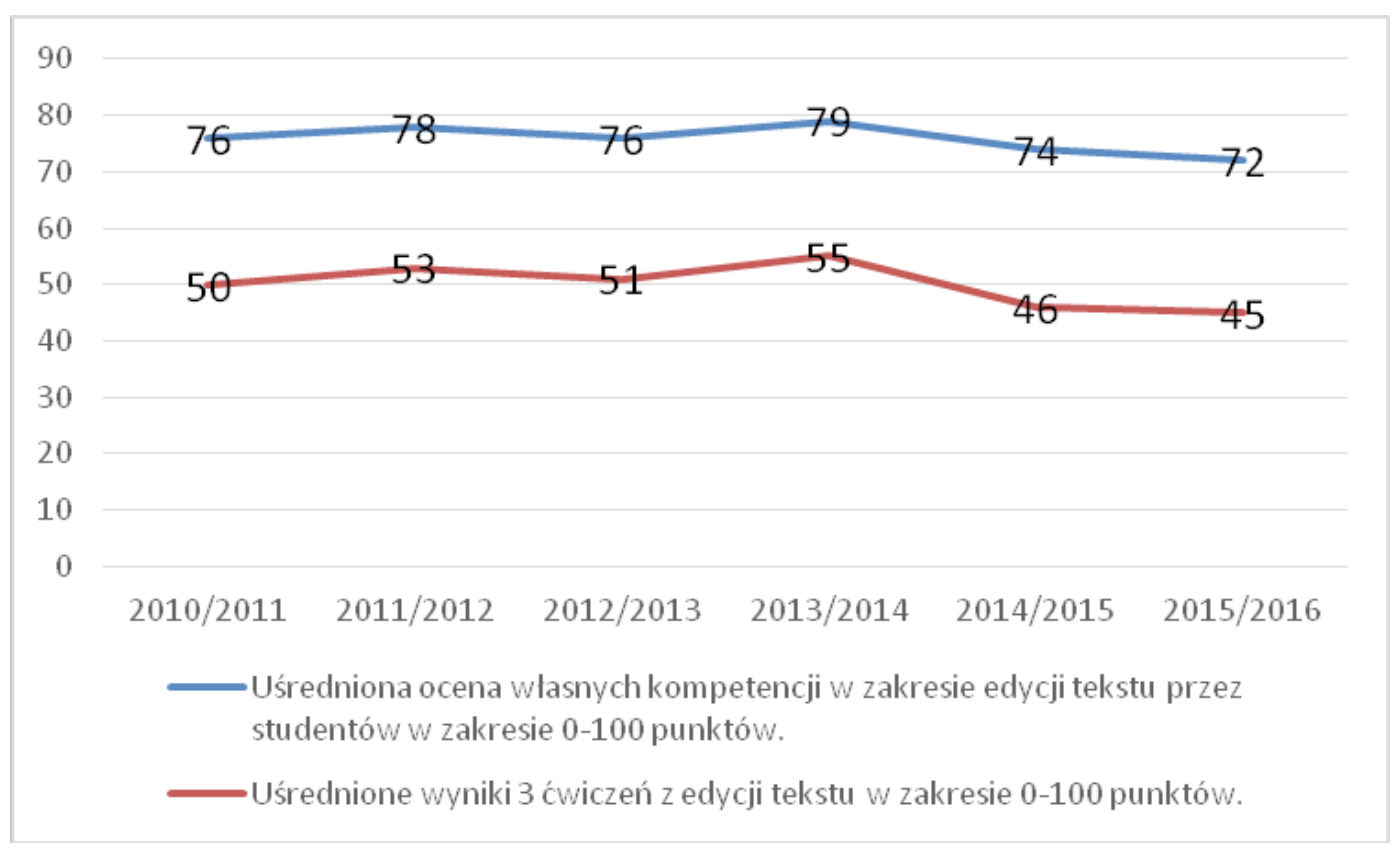

\section{Wykres nr 3: Ocena własnych kompetencji studentów oraz uśrednione oceny $\mathrm{z}$ trzech ćwiczeń edytorskich realizowanych w trakcie zajęć (każde ćwiczenie oceniane było w skali od 1 do 100 punktów)}

Jednym z elementów badania, który jest istotny dla określenia kompetencji informatycznych studentów, była samodzielna wypowiedź dotycząca zagrożeń związanych z dynamicznym rozwojem technologii informatycznych oraz cyberświata zagarniającego coraz więcej przestrzeni zarezerwowanej dotychczas dla przestrzeni realnej. Analizując wypowiedzi studentów, zwracałem uwagę na kilka elementów: wypowiedzi zdecydowanie krytyczne, pesymistycznie oceniające wpływ technologii na życie jednostek,

${ }^{18}$ Nawiązując do cytowanych zapisów podstaw programowych dla obowiązkowej w szkole podstawowej, gimnazjum oraz liceum informatyki, dodam, że w szkole podstawowej (klasy 1-6) zajęcia z komputerem trwają 190 godzin, w gimnazjum 65 godzin, zaś w szkole średniej 30 godzin. Biorąc pod uwage cytowane zapisy podstaw programowych, podaną wyżej liczbę godzin przeznaczonych na ten przedmiot oraz fakt, że w każdej z prowadzonych przeze mnie grup jedna do dwóch osób (na kilkanaście) potwierdza fakt uczestniczenia w ćwiczeniach z edycji tekstu, śmiem postawić tezę, że (przynajmniej w przypadku studentów, których miałem przyjemność uczyć) są one fikcją i w tym kontekście są nie tylko stratą czasu, ale również marnotrawstwem publicznych pieniędzy przeznaczonych na (z założenia) nowoczesne kształcenie młodzieży. 
wypowiedzi wyważone, zwracające uwagę zarówno na zagrożenia, jak i na plusy wynikające z dostępu do nowoczesnych technologii, wypowiedzi zdecydowanie entuzjastyczne, optymistycznie oceniające wpływ technologii na świat realny. Na wykresie nr 4 umieszczono trzy linie pokazujące na zmianę stosunku do technologii w czasie - zwraca uwagę narastanie ocen pesymistycznych, zmniejszanie się ocen umiarkowanych oraz stopniowe zmniejszanie się ocen zdecydowanie optymistycznych.

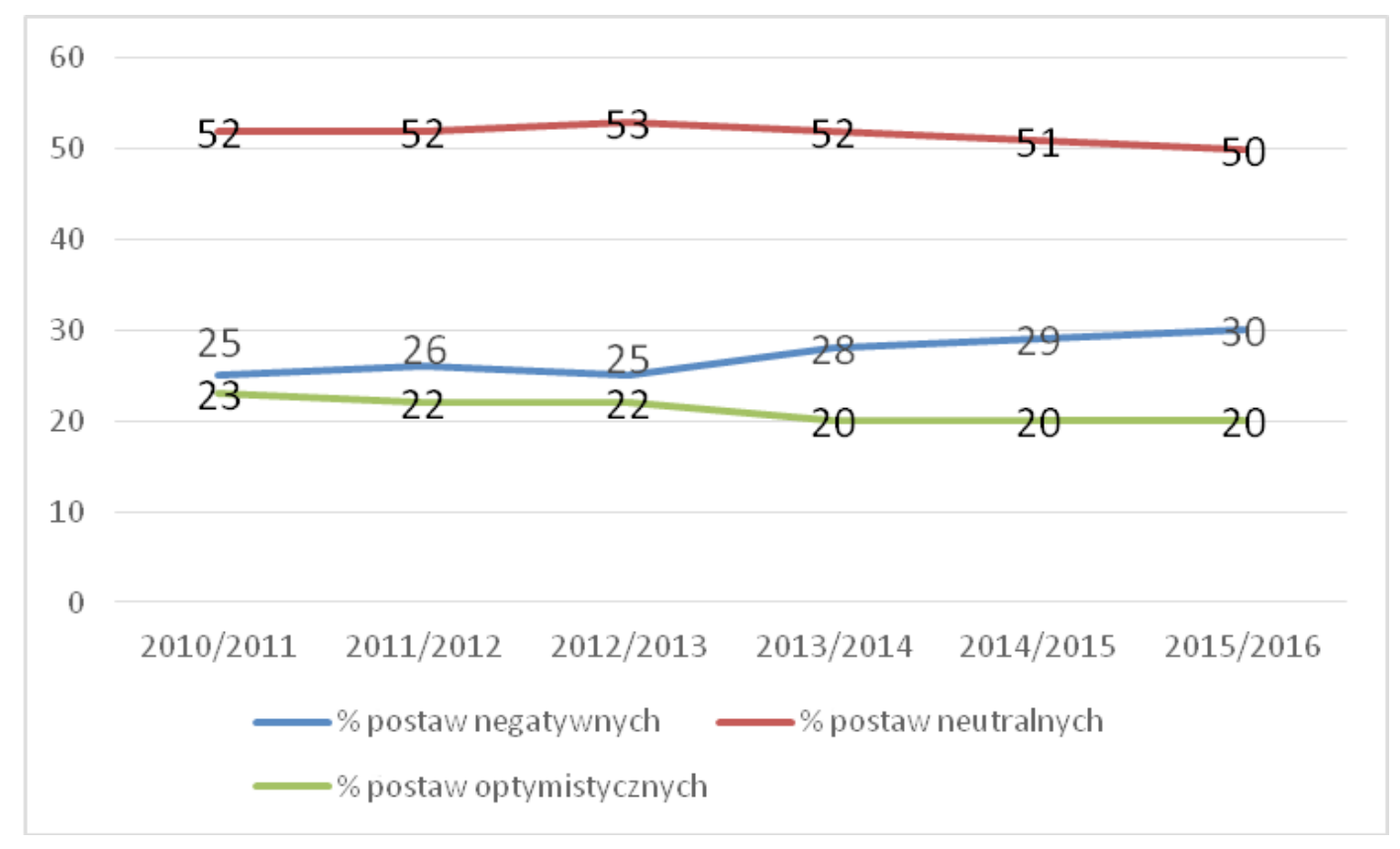

\section{Wykres nr 4: Studenckie postawy wobec przyszłości rozwoju technologii}

Badanie to $\mathrm{w}$ interesujący sposób współgra z wynikami trzech pytań ankietowych dotyczących metod łączenia się z Internetem, korzystania z narzędzi informatycznych oraz częstotliwości obecności w cyberprzestrzeni. Zaprezentowane na wykresach nr 5,6 i 9 wyniki wskazują, że młodzi ludzie są coraz bardziej niezależni w dostępie do Internetu od domu czy uczelni (od roku 2012 następuje radykalny wzrost liczby studentów korzystających z Internetu na własnych urządzeniach mobilnych z wykorzystaniem prywatnego połączenia internetowego) oraz (lub może w związku z tym) bardzo istotnie zwiększył się czas ich obecności w cyberprzestrzeni - od roku 2014 w pytaniu ankietowym dotyczącym czasu obecności w sieci Internetu nastąpił bardzo duży wzrost odpowiedzi dla zakresu "14-24” godziny dziennej aktywności/obecności w sieci ${ }^{19}$. Potwierdza to $\mathrm{z}$ jednej strony tezę, że współczesne młode pokolenie jest pokoleniem online, z drugiej zaś strony nie można pominąć w tym kontekście wyników zaprezentowanych na wykresie nr 5 - być może bowiem zwiększona lub nawet stała obecność w sieci powoduje pojawianie się coraz większej grupy lęków

\footnotetext{
${ }^{19} \mathrm{~W}$ związku z tym od roku 2016 dodana została dodatkowa opcja w tym pytaniu: „zawsze” dla osób, które są online stale.
} 
i zagrożeń związanych z coraz silniejszym wpływem technologii na życie codzienne, zagrożeń związanych z bezpieczeństwem w sieci (wiadomo, że jest ono iluzoryczne), ochroną prywatności w realiach ekshibicjonistycznych portali społecznościowych, hejtem, spamem i wszechobecną cyfrową reklamą opierającą się na inwigilowaniu internautów.

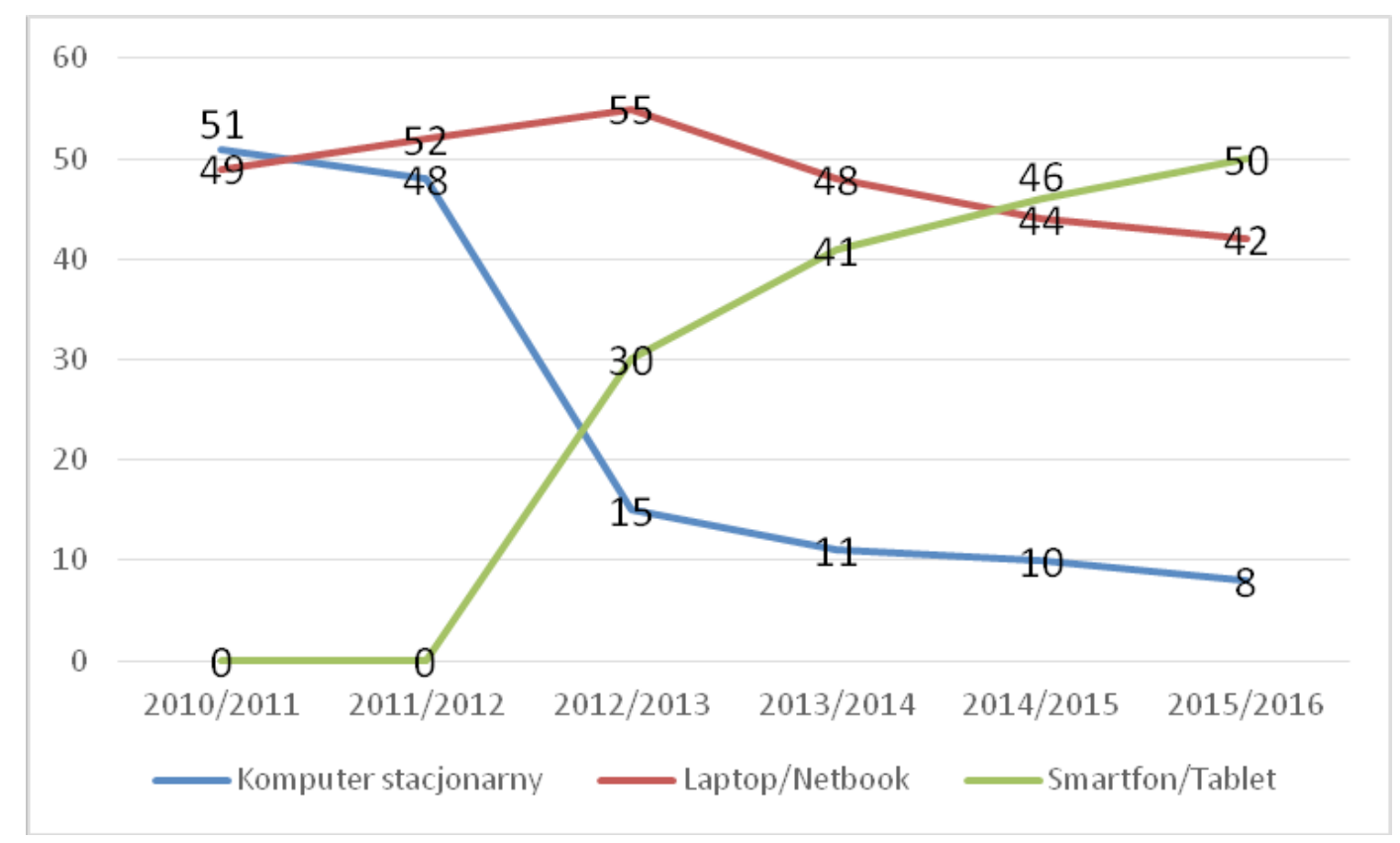

Wykres nr 5: Urządzenie, z którego studenci najczęściej łączą się z Internetem (tylko jedno)

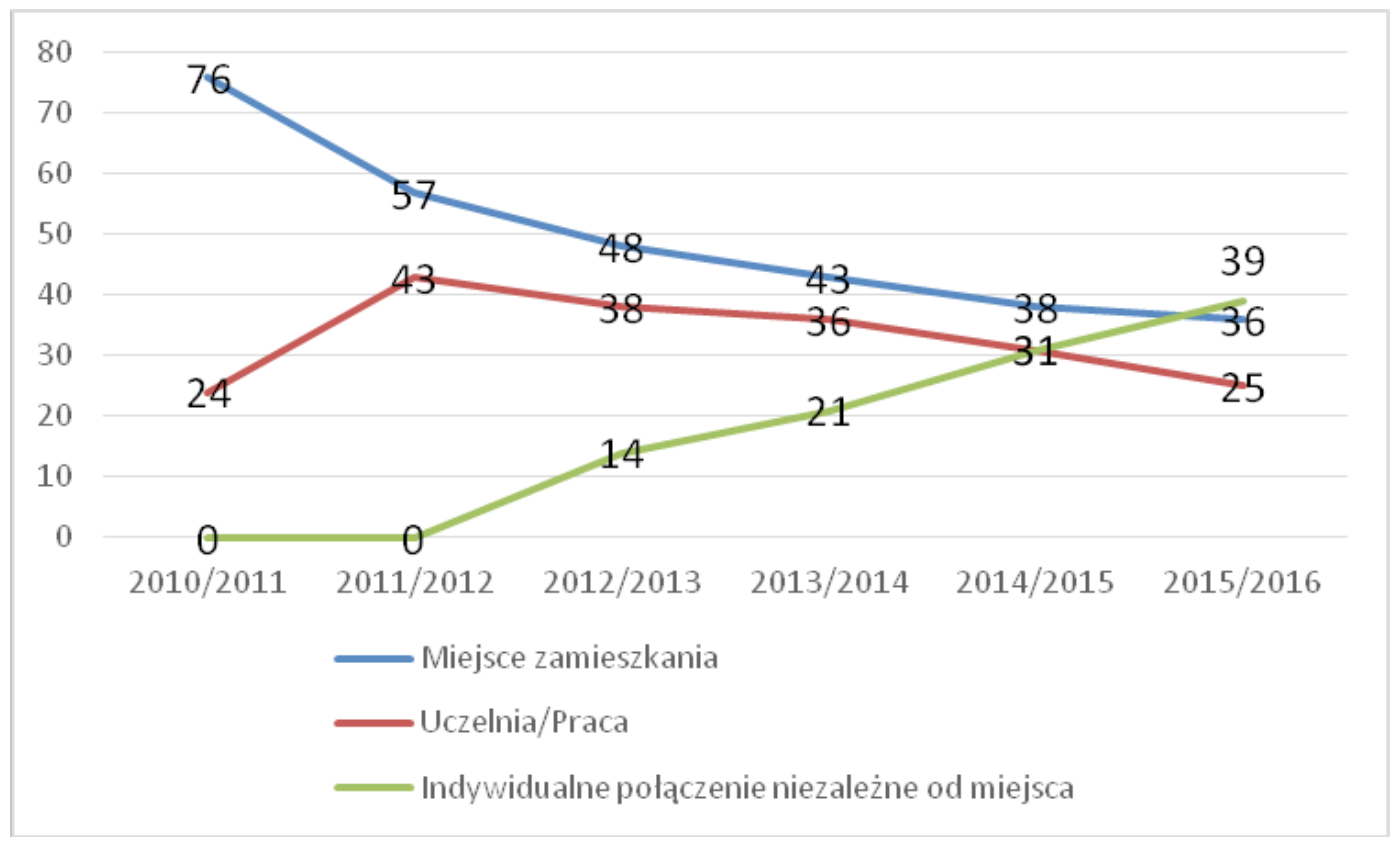

Wykres nr 6: Najczęściej wybierany sposób łączenia się z Internetem (można było wybrać tylko jedną metodę połączeń)

Polonistyka. Innowacje 


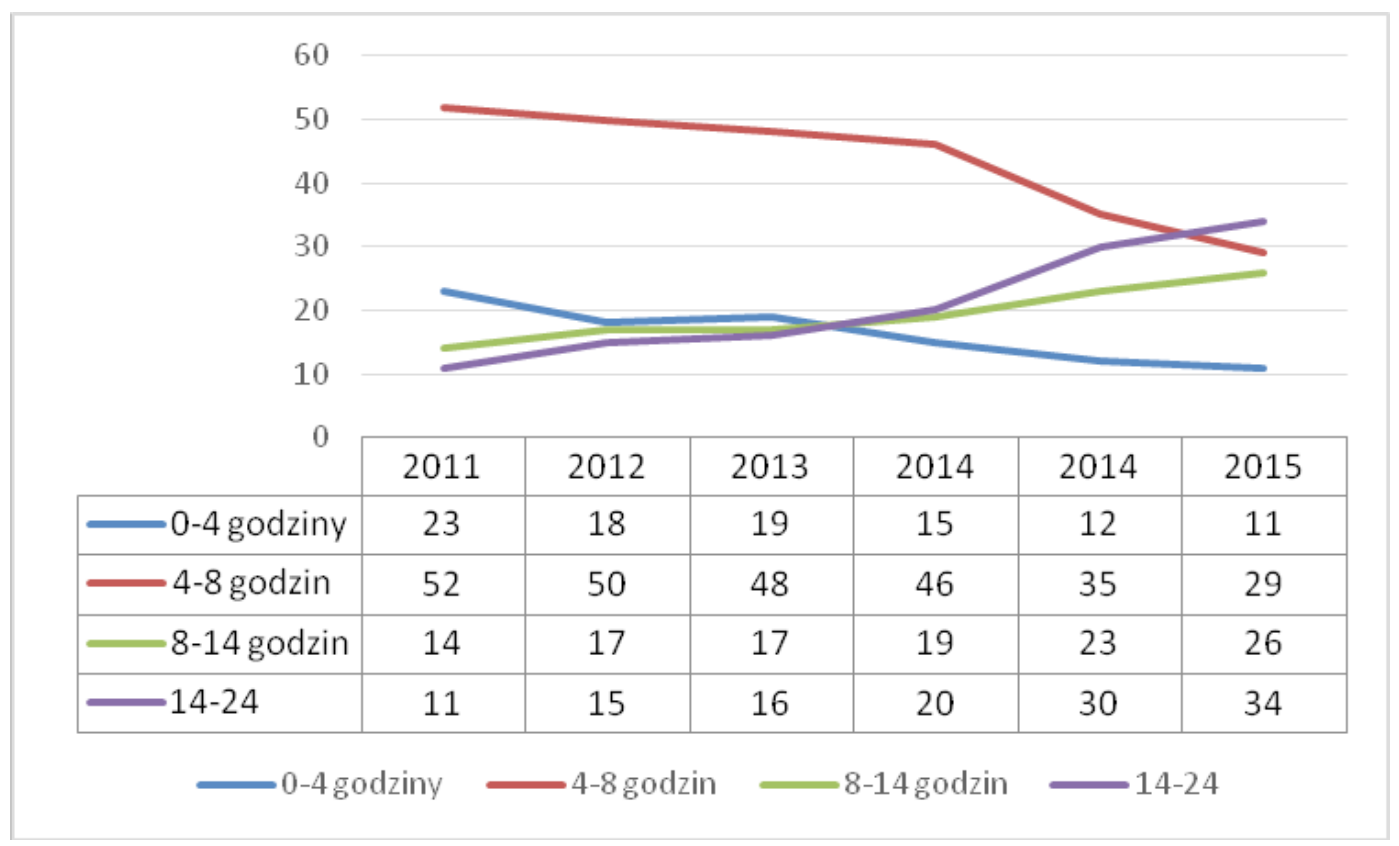

Wykres nr 7: Czas przeznaczony na dzienne połączenia z Internetem (bierne i czynne)

W tym kontekście, choć jest to już poza tematem niniejszego artykułu, warto również wziąć pod uwagę wynik badania ewaluacyjnego zajęć, w którym studenci od roku akademickiego 2010/11 pytani byli o preferencje dotyczące formy prowadzenia przedmiotu „Edukacja naukowo-informatyczna”. Do wyboru mieli trzy warianty: a) wszystkie zajęcia (teoretyczne i praktyczne) prowadzone $\mathrm{w}$ pracowni komputerowej, b) zajęcia prowadzone $\mathrm{w}$ formule mieszanej (blended learning) - teoria online, ćwiczenia praktyczne w pracowni komputerowej, c) wszystkie zajęcia online. Znaczące jest w tym przypadku, że od czasu pierwszego badania liczba zwolenników e-learningu, wskazujących tę formę kształcenia jako najdogodniejszą, spadła z $54 \%$ aż do $27 \%$.

Czyżby zaprezentowane powyżej wyniki badań stanowiły sygnał, że dojrzewa pierwsze pokolenie krytyczne wobec technologii i „dobrodziejstw” nowoczesności?

\section{Wnioski}

Przedstawione powyżej wybrane wyniki badań ${ }^{20}$ prowadzonych z udziałem studentów filologii polskiej na Wydziale Filologii Polskiej i Klasycznej UAM w Poznaniu w ramach prowadzenia zajęć „Edukacja naukowo-informatyczna" w latach 2010-2016 pozwalają na wysnucie kilku wniosków. Po pierwsze, studenci pierwszego roku filologii polskiej posiadają wiedzę dotyczącą współczesnych zjawisk związanych z tworzącym się

${ }^{20}$ Pełne wyniki badań wraz ze szczegółowym komentarzem autora znajdą się w zaplanowanej do wydania w roku 2017 publikacji Technologie informatyczne w kształceniu polonistów. Analiza form i metod stosowania technologii informatycznych $w$ obszarze nauk humanistycznych na przykładzie platformy informatycznej Wydziału Filologii Polskiej i Klasycznej UAM w Poznaniu. 
społeczeństwem informacyjnym i sieciowym na poziomie średnim z tendencją do niskiego. W zdecydowanej większości swoją wiedzę informatyczną czerpią ze źródeł pozaszkolnych, posiadają minimum wiedzy dostępnej typowym uczestnikom świata cyfrowego. Nie posiadają wystarczającej wiedzy dotyczącej praw autorskich, ochrony prywatności czy szeroko pojmowanego bezpieczeństwa w sieci. W odpowiedziach dotyczących edukacji informatycznej w poprzednich etapach edukacji udzielonych $\mathrm{w}$ badaniu ankietowym oraz $\mathrm{w}$ rozmowach przeprowadzonych $\mathrm{w}$ trakcie zajęć skarżą się na fikcyjność szkolnej edukacji informatycznej. Po drugie, studenci posiadają umiejętności informatyczne związane z edycją tekstu oraz tworzeniem dokumentów elektronicznych na poziomie niskim lub bardzo niskim. Nieliczne osoby posiadające omawiane umiejętności na poziomie dobrym lub wysokim w większości uzyskują je samodzielnie lub zawdzięczają je nauczycielowi-pasjonatowi, który prowadził np. szkolną gazetkę lub szkolny portal internetowy. Po trzecie, w wypowiedziach pisemnych studentów ujawnia się narastające zagubienie i zaniepokojenie dynamicznym rozwojem technologii. Po czwarte, studenci w ankiecie ewaluacyjnej zajęć w zdecydowanej większości domagają się ćwiczeń i warsztatów w pracowni komputerowej, które pozwolą im podnieść kompetencje informatyczne.

Analizując wyniki w całości (a także wsłuchując się w głosy pracodawców zatrudniających absolwentów szkół średnich i wyższych krytycznie oceniających ich kompetencje informatyczne i komunikacyjne ${ }^{21}$ ), można postawić tezę, że bez kompleksowej reformy edukacji informatycznej na wszystkich etapach edukacji, z uniwersytecką włącznie, trudno wyobrazić sobie wyraźny i oczekiwany przez decydentów „impuls innowacyjny” polskiego społeczeństwa w najbliższych i nieco odleglejszych latach.

\section{Literatura}

Bednarek Józef, 2002, Multimedia w kształceniu, Warszawa.

Castells Manuel, 1996, The Rise of the Network Society, wyd. pol. 2007, Społeczeństwo sieci, Warszawa.

Dijk van Jan, 1999, The Network Society: Social Aspects of New Media, wyd. pol. 2010, Społeczne aspekty nowych mediów. Analiza społeczeństwa sieci, Warszawa.

Fowler J.H., Christakis N.A., 2009, Connected: The Surprising Power of Our Social Networks and How They Shape Our Lives, New York, wyd. pol. 2011, $W$ sieci, Sopot.

Innowacje i metody. Tom 1. W kręgu teorii i praktyki. Podręcznik akademicki dydaktyki kształcenia polonistycznego, 2011, Kwiatkowska-Ratajczak M. (red.), Poznań.

Kron Friedrich W., Sofos Alivisos, 2008, Dydaktyka mediów, Gdańsk.

Media a edukacja, t. 1, 2, 3, 1997, 1998, 2000, Strykowski W. (red.), Poznań.

${ }^{21}$ Zob. Polonista na rynku pracy, 2016, Gis A., Wobalis M. (red.), Poznań.

\section{Polonistyka. Innowacje}


Naisbitt John, 1997, Megatrendy, Poznań.

Oblicza Internetu. Sieciowe dyskursy (Roz)poznawanie cyfrowego świata, 2014, Sokołowski M. (red.), Elbląg.

Pedagogika medialna: podręcznik akademicki, 2007, Siemieniecki B. (red.), Warszawa.

Polonista na rynku pracy, 2016, Gis A., Wobalis M. (red.), Poznań.

Puppel Stanisław, 2008, The Internet and the Web: a universal tool and a global resource for tayloring customized foreign language learning toolkits, w: Tom jubileuszowy z okazji 70. urodzin Profesora Waldemara Pfeiffera, Poznań, s. 265-274.

Steinbrink Bernard. 1993, Multimedia. U progu XXI wieku, Wrocław.

Toffler Alvin, 1997, Trzecia Fala, Warszawa.

Wobalis Mirosław, 2011, Multimedia i ich wpływ na edukację i uczenie się, w: Innowacje i metody. Tom 1. W kręgu teorii i praktyki. Podręcznik akademicki dydaktyki kształcenia polonistycznego, Kwiatkowska-Ratajczak M. (red.), Poznań.

Zacher Lech W., 2014, Hybrydowy świat człowieka i ewolucja systemów socjotechnicznych, w: Oblicza Internetu. Sieciowe dyskursy. (Roz)poznawanie cyfrowego świata, Sokołowski M. (red.), Elbląg.

\section{O Autorze:}

Mirosław Wobalis - adiunkt w Zakładzie Nauk Pomocniczych i Edytorstwa IFP UAM w Poznaniu. Autor i redaktor kilkunastu publikacji, w tym m.in. książki Multimedia w nauczaniu polonistycznym (2015). Twórca i administrator Serwisu Edukacji Interaktywnej WFPiK UAM w Poznaniu. Wydziałowy koordynator ds. kształcenia na odległość. 